\title{
Psychotria gopalanii (Rubiaceae): A new species from Eastern Ghats, India
}

\author{
S. Sambooranam \\ Centre for Plant Taxonomy and Floristic Research, Department of Botany, Karpagam University, \\ Coimbatore - 641021, Tamil Nadu, India. \\ E-mail: sambusubu@gmail.com
}

\begin{abstract}
Psychotria gopalanii Samb., a new species is described and illustrated from Erode Forest Division in the Eastern Ghats of Tamil Nadu.
\end{abstract}

Keywords: Eastern Ghats, New Species, Psychotria, Rubiaceae

\section{Introduction}

Rubiaceae are the fourth largest angiosperm family consisting of $c$. 13,183 species in 611 genera, of which Psychotria L. is the largest genus in the family (c. 1834 spp.) and is the third largest genus of angiosperms (Davis et al., 2009). In India, Rubiaceae are the fifth largest family comprising 4 subfamilies, 28 tribes, 113 genera with 616 species (Deb, 2001), and Psychotria is reported to have 44 species (Murugan \& Gopalan, 2007). With the addition of $P$. henryana from Kanyakumari (Murugan \& Gopalan, 2007) and P. vasudevae from Andaman and Nicobar Islands (Murugan \& Arisdason, 2016), the total number of species now becomes 46 in the country. Pullaiah et al. (2007) recorded six species from Eastern Ghats of India. Psychotria is reported to have 17 species and 2 varieties in Tamil Nadu (Swaminathan, 1987), of which P. sohmeri M. Kiehn and P. octosulcata Talbot are distributed in Eastern Ghats of the state.

While studying the floristic account of the Erode Forest Division in the Eastern Ghats of Tamil Nadu, the author collected an interesting specimen of Psychotria. On critical examination of herbarium specimens at $\mathrm{MH}$ and perusal of relevant literature, it was found to be an undescribed species. Hence, the same is described here with illustrations and colour photographs for easy recognition identification in field.

Psychotria gopalanii Samb., sp. nov.

Figs. 1, 2

Diagnosis: Psychotria gopalanii closely related to $P$. sohmeri $\mathrm{M}$. Kiehn, but differing in the lenticelllate bark, ligulate, bifurcate and keeled stipules, bracteolate flowers, smooth margins of calyx teeth, strongly recurved corolla lobes and smooth stigma.
Type: INDIA, Tamil Nadu, Erode District, Anthiyur R.F., Bolly, $11^{\circ} 41^{\prime} 26.99^{\prime \prime}$ N, 77³0'7.78" E, 1386 m, 2.7.2015, S. Sambooranam 686 (Holotype, CAL; Isotypes MH).

Shrub, c. $3 \mathrm{~m}$ high. Stems terete; branchlets lenticellate; internodes $1.5-2 \mathrm{~cm}$ long. Leaves simple, opposite-decussate, obovate-oblanceolate or elliptic-oblong, $1.5-11 \times 0.8-6.5 \mathrm{~cm}$, attenuate at base, entire at margins, acute-acuminate at apex, subcoraiceous, glabrous, dark green, shiny above, pale green beneath; lateral veins 8-12 pairs; midrib prominent, infossous above, raised beneath, intramarginally looped; domatia glabrous; stipules broadly ovate, $c .1 .5 \mathrm{~cm}$ long, keeled, caducous, midrib rufous-hairy inside, base ligulate inside; ligules 4-lobed, densely rufoushairy, lobes acuminate at apex, persistent; petioles c. $1.5 \mathrm{~cm}$ long, canaliculate above, rounded beneath. Inflorescences terminal, paniculate racemose cymes, 8-13 cm long; peduncles c. 4.5 $\mathrm{cm}$ long, minutely grooved; flowering branches spirally arranged, stout, to $1 \mathrm{~cm}$. Flowers 6-7 mm long; bracteoles linear, minute, caducous; pedicels 1-2 mm long. Calyx tube 1-1.3 mm long; lobes 5, minute, glabrous. Corolla tube $3-4 \mathrm{~mm}$ long, narrow, glabrous outside, with a rim of white villous-hairy above the middle inside; lobes 5 , lanceolate, c. $2.5 \mathrm{~mm}$ long, thick, recurved at apex. Stamens 5, exserted; filaments $1.5-2 \mathrm{~mm}$ long, erect, adnate to corolla throat; anthers oblong, $0.5-1 \mathrm{~mm}$ long, dorsifixed. Ovary bilocular; ovule 1 in each locule; style c. $3 \mathrm{~mm}$ long, dilated towards apex, included; stigma bifid, ovate or tongue-shaped, smooth Fruits globose, c. $1 \mathrm{~cm}$, 10-ribbed, apex with persistent calyx lobes; testa thin; pyrenes plano-convex; albumin ruminate. 

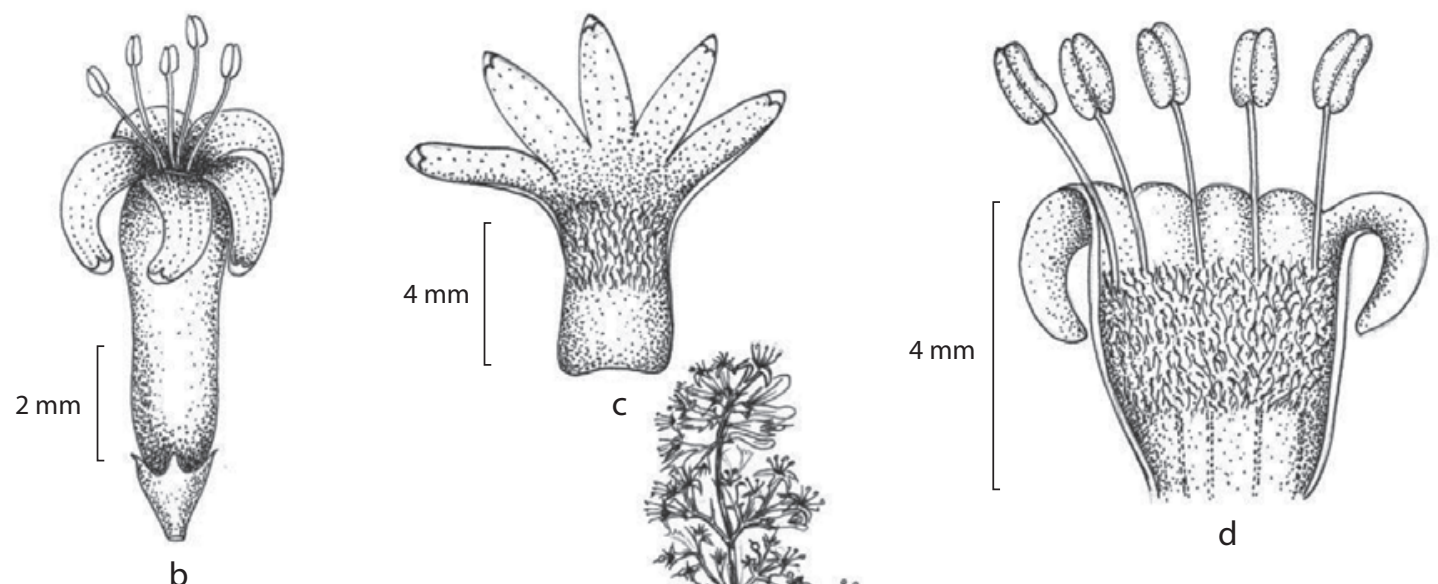

d

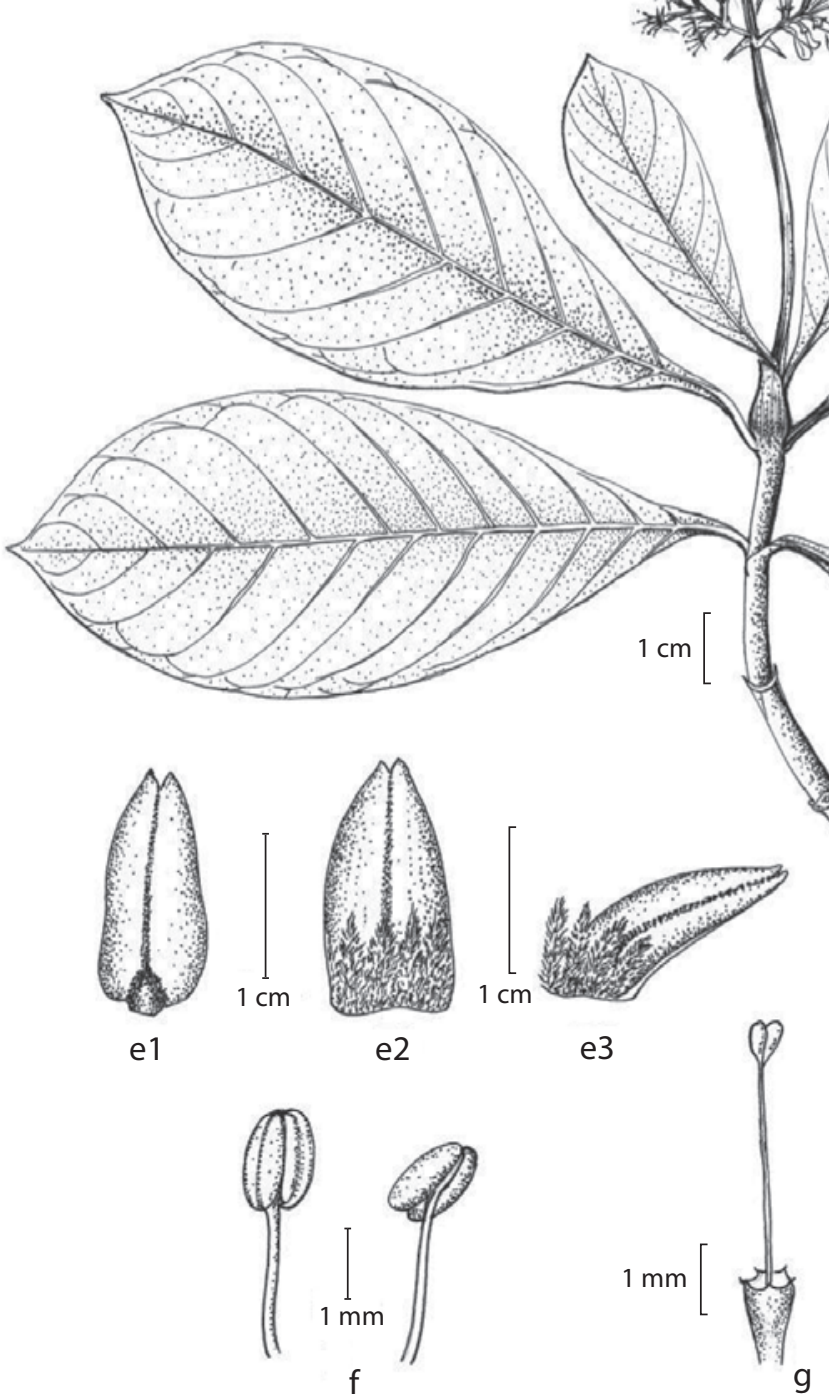

Fig. 1. Psychotria gopalanii Samb.: a. Flowering-twig; b. Flower; c. Corolla; d. Corolla with stamens split-open; e1-3. Stipule dorsal, ventral and lateral views; f. Stamens; g. Pistil; $h$. Fruit. 

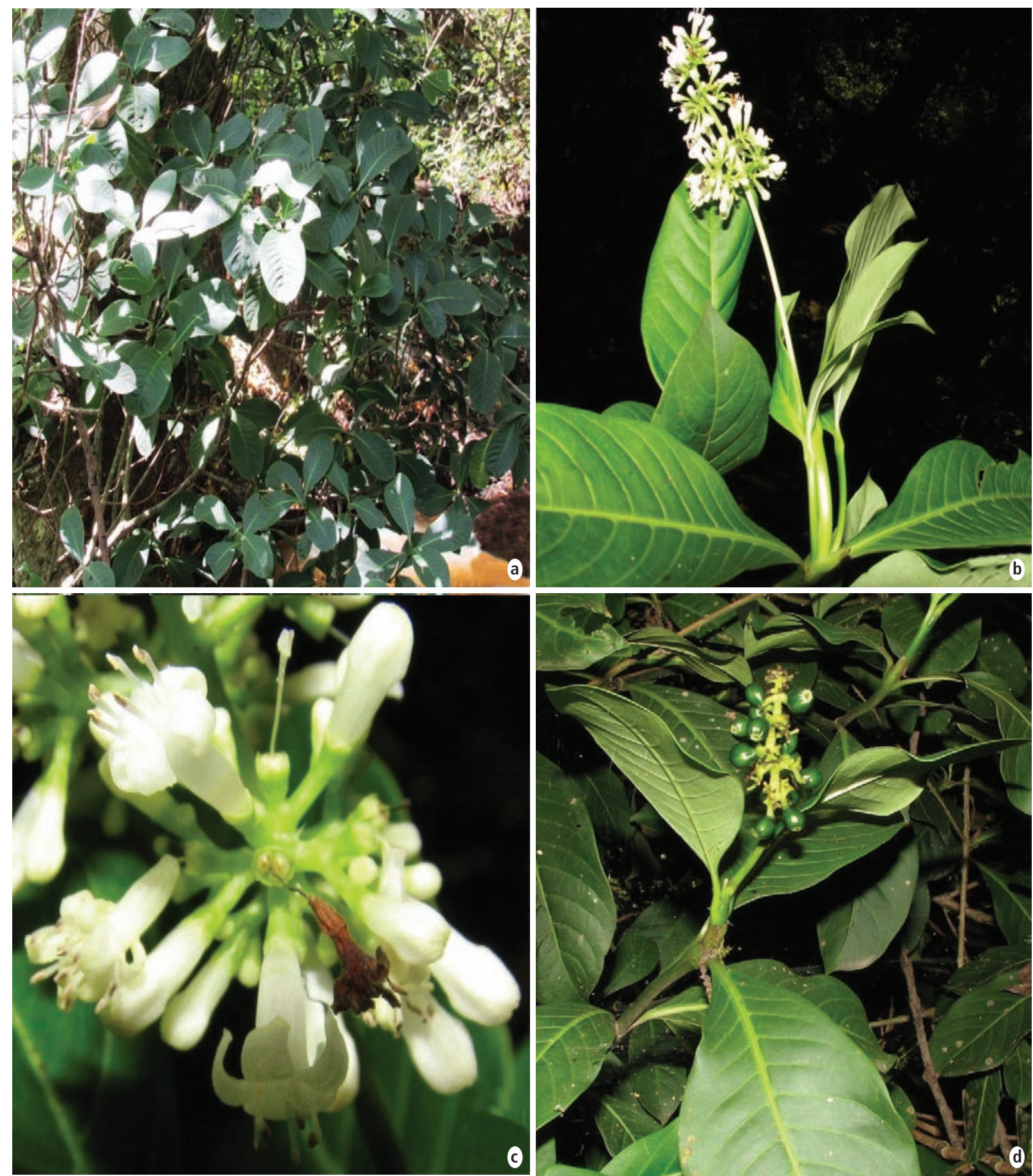

Fig. 2. Psychotria gopalanii Samb.: a. Habit; b. Flowering-twig; c. Inflorescence (a portion (top view) enlarged); d. Fruiting-twig.

Flowering \& Fruiting: March-September.

Habitat: Along the streams in the gorges of Phoenix savannah, at $1386 \mathrm{~m}$ elevation.

Distribution: India: Tamil Nadu (Erode district). Endemic.

Etymology: The new species is named in honour of Dr. R. Gopalan, former Scientist, Botanical Survey of India (BSI), Southern Regional Centre (SRC), Coimbatore, for his contribution to the Indian plant taxonomy.

Conservation Status: This species is currently known only from type locality. Further botanical explorations are needed to evaluate the status of the species as per the guidelines of IUCN Categories and Criteria. 
Table. Comparison of morphological characters between Psychotria sohmeri and P. gopalanii

\begin{tabular}{lll}
\hline Characters & Psychotria sohmeri & P. gopalanii, sp. nov. \\
\hline Branchlets (texture) & Smooth & Lenticellate \\
Leaves & $5-17 \times 2.5-7 \mathrm{~cm}$ & $1.5-11 \times 0.8-6.5 \mathrm{~cm}$ \\
Lateral veins & $10-20$ on each side & $8-12$ on each side \\
Stipules & Ovate-oblong, $0.6-2 \times 0.4-1 \mathrm{~cm}$, & Broadly ovate, keeled, $1-1.5 \times$ \\
& villous beneath at base, ligule absent, & $0.4-0.7 \mathrm{~cm}$, glabrous at margins, \\
& ciliate or puberulous at margins, & ligulate inside, ligule 4-lobed, lobes \\
& emarginate at apex & and midrib densely rufous-hairy, \\
& & acute when young and bifurcate at \\
& & maturity \\
Inflorescence & Paniculate cymes, 5-9 $\times 1-2 \mathrm{~cm}$ & Paniculate racemose cymes, \\
& & $8-13 \times 1.5-3.5 \mathrm{~cm}$ \\
Bracteoles & Absent & Linear, minute, glabrous \\
Calyx teeth & Puberulous at margins & Glabrous at margins \\
Corolla lobes & Slightly incurved & Strongly recurved \\
& Rim of villous hairs at throat & Rim of villous hairs below the throat \\
Stigma & Papillose & Smooth \\
\hline
\end{tabular}

Note: Psychotria gopalanii Samb. is morphologically closely allied to P. sohmeri $\mathrm{M}$. Kiehn, but differs in many other characters as shown in the Table.

\section{Acknowledgements}

The author is grateful to the Principal Chief Conservator of Forests, Chennai and Conservator of Forests, Erode Circle, Tamil Nadu Forest Department, for permission and facilities extended during the course of study. The author is also thankful to the Management of Karpagam University, for constant support and the Scientistin-Charge, BSI, SRC, Coimbatore, for permitting to consult the herbarium.

\section{Literature Cited}

Davis, A.P., Govaerts, R., Bridson, D.M., Ruhsam, M., Moat, J. \& N.A. Brummitt 2009. A global assessment of distribution, diversity, endemism and taxonomic effort in the Rubiaceae. Ann. Missouri Bot. Gard. 96(1): 68-78.

Deb, D.B. 2001. Rubiaceae. In: Singh, N.P. \& D.K. Singh (eds.), Floristic Diversity and Conservation Strategies in India. Vol. 4. Botanical Survey of India, Kolkata. pp. 1961-1981.
Deb, D.B. \& M. Gangopadhyay 1989. Taxonomic revision of the genus Psychotria (Rubiaceae) in India. J. Econ. Taxon. Bot., Addit. Ser. 7: $1-166$.

Murugan, C. \& R. Gopalan 2007. Psychotria henryana (Rubiaceae), a new species from the southern Western Ghats, India. Nordic J. Bot. 24(4): 415-418.

Murugan, C. \& W. Arisdason 2016. A new species of Psychotria (Rubiaceae) from Andaman and Nicobar Islands, India. Phytotaxa 258(3): 295-300.

Pullaiah, T., Ramamurthy, S.K. \& S. Karuppusamy 2007. Flora of Eastern Ghats, Hill Ranges of South East India. Vol. 3. Regency Publications, New Delhi. pp. 192-196.

Swaminathan, M.S. 1987. Rubiaceae. In: Henry, A.N., Kumari, G.R. \& V. Chithra (eds.), Flora of Tamil Nadu, India. Series 1: Analysis. Vol. 2. Botanical Survey of India, Coimbatore. pp. $1-27$.

Received: 6.9.2016

Revised and Accepted: 7.6.2017 